\title{
Intracellular accumulation of aggregated pyroglutamate amyloid beta: convergence of aging and $A \beta$ pathology at the lysosome
}

\author{
Line De Kimpe • Elise S. van Haastert • \\ Archontia Kaminari • Rob Zwart • Helma Rutjes • \\ Jeroen J. M. Hoozemans • Wiep Scheper
}

Received: 25 November 2011 / Accepted: 9 March 2012 / Published online: 4 April 2012

(C) The Author(s) 2012. This article is published with open access at Springerlink.com

\begin{abstract}
Deposition of aggregated amyloid beta $(A \beta)$ is a major hallmark of Alzheimer's disease (AD) - a common age-related neurodegenerative disorder. Typically, $A \beta$ is generated as a peptide of varying lengths. However, a major fraction of $A \beta$ peptides in the brains of $\mathrm{AD}$ patients has undergone posttranslational modifications, which often radically change the properties of the peptides. $A \beta_{3(\mathrm{pE})-42}$ is an Ntruncated, pyroglutamate-modified variant that is abundantly present in AD brain and was suggested to play a role early in the pathogenesis. Here we show that intracellular accumulation of oligomeric aggregates of $\mathrm{A} \beta_{3(\mathrm{pE})-42}$ results in loss of lysosomal
\end{abstract}

Electronic supplementary material The online version of this article (doi:10.1007/s11357-012-9403-0) contains supplementary material, which is available to authorized users.

L. De Kimpe · A. Kaminari · R. Zwart · W. Scheper

Department of Genome Analysis,

Academic Medical Center,

Meibergdreef 9,

1105 AZ Amsterdam, The Netherlands

E. S. van Haastert · J. J. M. Hoozemans

Department of Pathology, VU University Medical Center,

De Boelelaan 1117,

1081 HV Amsterdam, The Netherlands

H. Rutjes

Hycult Biotech,

Frontstraat 2a,

5405 PB Uden, The Netherlands integrity. Using a novel antibody specific for aggregates of $\mathrm{A} \beta \mathrm{pE} 3$, we show that in postmortem human brain tissue, aggregated $\mathrm{A} \beta \mathrm{pE} 3$ is predominantly found in the lysosomes of both neurons and glial cells. Our data further demonstrate that $\mathrm{A} \beta \mathrm{pE} 3$ is relatively resistant to lysosomal degradation, which may explain its accumulation in the lysosomes. The intracellular $\mathrm{A} \beta \mathrm{pE} 3$ aggregates increase in an age-dependent manner. The results presented in this study support a model where $A \beta$ pathology and aging converge, leading to accumulation of the degradation-resistant pE-modified $A \beta$ in the lysosomes, lysosomal dysfunction, and neurodegeneration.

\footnotetext{
W. Scheper $(\bowtie)$

Department of Genome Analysis,

Academic Medical Center,

P.O. Box 22660, 1100 DE Amsterdam, The Netherlands

e-mail: w.scheper@amc.uva.nl
} 
Keywords Alzheimer's disease · Pyroglutamate amyloid beta $\cdot$ Lysosomal pathology

\section{Abbreviations}

AD Alzheimer's disease

A $\beta \quad$ Amyloid beta

$\mathrm{pE} \quad$ Pyroglutamate

QC Glutaminyl cyclase

LMP Lysosomal membrane permeabilization

\section{Introduction}

Alzheimer's disease (AD) is a common progressive neurodegenerative disorder of which the prevalence is steeply increasing in the aging society. Neuropathologically, $\mathrm{AD}$ is characterized by deposits of aggregated proteins: intracellular aggregates of hyperphosphorylated tau in neurofibrillary tangles and extracellular $\beta$-amyloid $(A \beta)$ in plaques. According to the widely supported amyloid cascade hypothesis, increased levels and the formation of assemblies of $\mathrm{A} \beta$ is one of earliest events in $\mathrm{AD}$ pathogenesis (Hardy and Selkoe 2002). Indeed, $A \beta$ is prone to self-aggregate and the formation of the resulting aggregates is strongly linked to the development of the disease. However, despite enormous research efforts, the exact site and mechanism of $\mathrm{A} \beta$ toxicity is still not entirely elucidated. A major obstacle in $A \beta$ research is that $A \beta$ is not a single entity but a peptide with great molecular heterogeneity (De Kimpe and Scheper 2010).

$A \beta$ is generated as a peptide of varying lengths by combined action of $\beta$ - and $\gamma$-secretase through proteolytic processing of the amyloid precursor protein (APP). Previously extracellular fibrillar $\mathrm{A} \beta$ as found in the plaques was considered to be the main toxic species. However, recently it has become apparent that soluble oligomeric $A \beta$ aggregates and intracellular $\mathrm{A} \beta$ play important roles in the pathogenesis of AD (Haass and Selkoe 2007).

In addition to the full-length $A \beta_{1-x}$ peptides, various modified $A \beta$ variants can be detected in the human brain (Saido et al. 1996). These variants are truncated at their N- or C-termini and/or harbor different posttranslational modifications resulting in the generation of $\mathrm{A} \beta$ peptides with different physical and chemical properties. An abundant $A \beta$ variant in human brain is the pyroglutamate $(\mathrm{pE})$-modified $\mathrm{A} \beta \mathrm{pE}$ 3. This $\mathrm{N}$-terminal $\mathrm{pE}$ modification of $\mathrm{A} \beta$ can be catalyzed by the enzyme glutaminyl cyclase (QC) (Schilling et al. 2004). A $\beta p E 3$ peptides show a higher stability (Kuo et al. 1998), increased aggregation propensity (Schilling et al. 2006), and neurotoxicity (Russo et al. 2002; Youssef et al. 2008) compared to the full-length unmodified $\mathrm{A} \beta$. A mouse model selectively expressing this variant shows that intraneuronal accumulation of $A \beta_{3(\mathrm{pE})-42}$ is sufficient for triggering neuronal loss and behavioral deficits (Wirths et al. 2009). This indicates that $A \beta_{3(p E)-42}$ is a pathogenic species relevant to the progression of the disease. Because of its aggregation ability, $\mathrm{A} \beta \mathrm{pE} 3$ has been suggested to provide the "seed" for the $A \beta$ aggregation in AD (Schilling et al. 2006). In support of this, prophylactic treatment with a $\mathrm{QC}$ inhibitor results in decreased $\mathrm{A} \beta_{\mathrm{x}-40 / 42}$ levels, reduced plaque burden, diminished gliosis, and improved spatial learning, as shown in two different APP transgenic mouse models (Schilling et al. 2008). Therefore, the $p E-$ modified $A \beta$ peptides are a potential target for the treatment of the disease. However, the precise role of $\mathrm{pE}$-modified $\mathrm{A} \beta$ in the pathogenesis of the disease is still elusive. In this study, we focused on the pathogenic involvement of non-fibrillar aggregates of $A \beta_{3(\mathrm{pE})-42}$. Previously, our group demonstrated that oligomeric $A \beta_{1-42}$ is rapidly internalized by neuronal cells to ultimately accumulate in the lysosomal compartment. Inhibition of uptake of oligomeric $A \beta_{1-42}$ decreases toxicity (Chafekar et al. 2008) suggesting that the lysosome is involved in $A \beta$ toxicity. In addition, dysfunction of the endo-/lysosomal pathway is an early phenomenon in AD pathology. From previous studies, it is know that lysosomal damage plays a role in soluble $A \beta_{1-42^{-}}$ mediated cell death (Ditaranto et al. 2001). Lysosomal dysfunction plays an important role in the disease (Nixon et al. 2008), but it is not known whether $\mathrm{A} \beta \mathrm{pE} 3$ affects the lysosomes. It is of interest to investigate the mode of toxicity of this specifically modified $A \beta$ form because its formation can potentially be prevented using a QC inhibitor. Therefore, in this study, we investigated the involvement of the lysosome in the pathomechanistic role of $\mathrm{A} \beta \mathrm{pE} 3$ aggregates. Using cell models, in vitro lysosomal degradation assays and analysis of postmortem human brain material, we obtained data that support a model showing convergence of $\mathrm{A} \beta \mathrm{pE} 3$ pathology and aging at the lysosome. 


\section{Results}

$\mathrm{A} \beta_{3(\mathrm{pE})-42}$ oligomers cause lysosomal membrane permeabilization

To investigate whether $A \beta_{3(\mathrm{pE})-42}$ oligomers affect the integrity of the lysosomes, lysosomal membrane permeabilization (LMP) was analyzed in differentiated SK-N-SH cells. A distinctive sign of LMP is the translocation of soluble lysosomal components, from the lysosomal lumen to the cytosol (Boya et al. 2003). Differentiated SK-N-SH cells were treated with A $\beta$ oligomers and the leakage of cathepsin D (CTD), a soluble lysosomal enzyme, from the lysosomal lumen to the cytosol was analyzed after subcellular fractionation on Western blot and by immunofluorescent staining. Treatment with $\mathrm{A} \beta_{3(\mathrm{pE})-42}$ oligomers led to a decrease of CTD in the membrane fraction (which also contained the lysosomes) whereas the cytosolic CTD was increased. However, treatment with $A \beta_{1-42}$ oligomers did not change the levels of CTD neither in the membrane fraction, nor in the cytosolic fraction (Fig. 1a). The result was confirmed by immunofluorescent staining of CTD. Untreated cells reveal a particulate staining pattern, indicative of its localization within lysosomes (Fig. 1b). After treatment with $A \beta_{3}$ (pE)-42 oligomers, the staining was less punctuate and bright but more diffusely distributed throughout the entire cytoplasm, indicating the enzyme had been released from the lysosomes to the cytoplasm. Treatment with hydroxychloroquine (HCQ), an established inducer of LMP, gave a similar result as the cells treated with the $A \beta_{3(\mathrm{pE})-42}$ oligomers. Treatment with $A \beta_{1-42}$ oligomers shows the same pattern but to a lesser extent.

Taken together these data demonstrate that $\mathrm{A} \beta_{3(\mathrm{pE})-42}$ oligomers are more potent inducers of LMP than $A \beta_{1-42}$ oligomers. LMP is toxic for cells because it leads to impaired lysosomal function and aberrant exposure of cellular components to lysosomal enzymes. Since Hsp70 has been reported to stabilize lysosomes and thereby inhibit LMP (Kirkegaard et al. 2010), we investigated if increased levels of Hsp70 could inhibit $\mathrm{A} \beta_{3(\mathrm{pE})-42}$ oligomer toxicity. Therefore mock- or Hsp70-transfected HeLa cells were treated with $2 \mu \mathrm{M}$ $\mathrm{A} \beta_{3(\mathrm{pE})-42}$ oligomers. Using the MTT cell viability assay, the effect of Hsp70 overexpression on $A \beta$ toxicity was analyzed. Overexpression of Hsp70 completely inhibited $A \beta_{3(\mathrm{pE})-42}$ oligomer toxicity (Fig. 1c). These
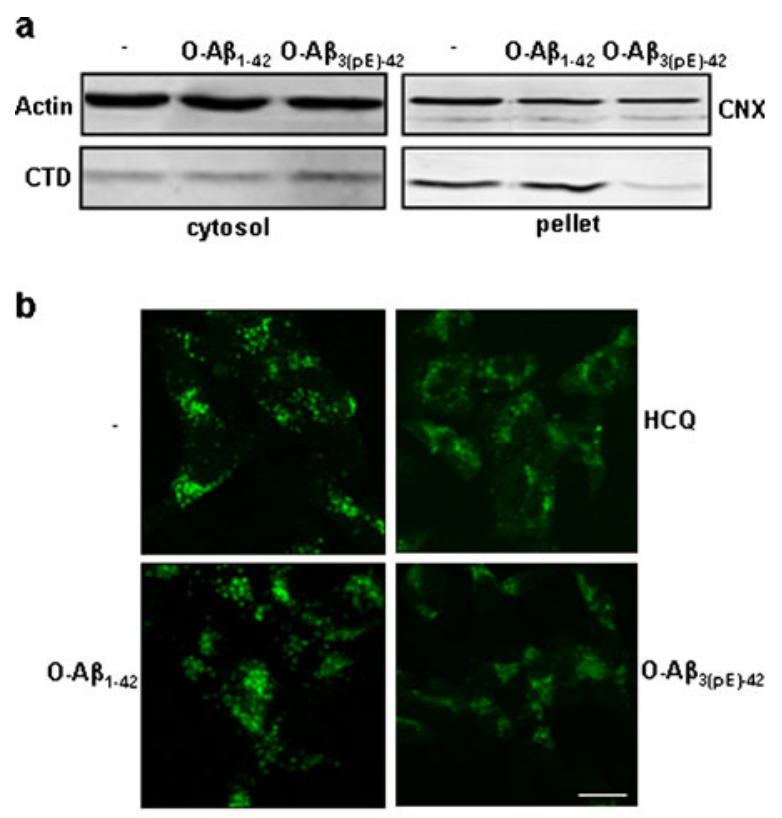

c

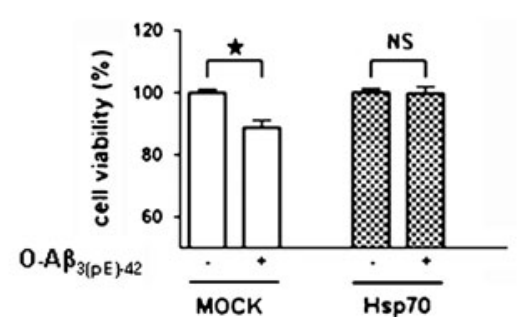

Fig. $1 \mathrm{~A} \beta_{3(\mathrm{pE})-42}$ oligomers cause LMP. a Western blot analysis showing the protein levels of CTD in the cytosolic and in the pellet fraction of untreated (minus sign) cells and after treatment with $1 \mu \mathrm{M} \mathrm{A} \beta_{1-42}$ or $\mathrm{A} \beta_{3(\mathrm{pE})-42}$ oligomers for $16 \mathrm{~h}$. $\beta$-actin and calnexin are depicted as protein loading control. The experiment was performed three times and representative blots are shown. b Confocal pictures of differentiated SK-N-SH cells after immunofluorescent staining of CTD on untreated (minus sign), HCQ-,

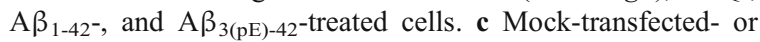
Hsp70-transfected HeLa cells were incubated in the absence (minus sign) or presence (plus sign) of $2 \mu \mathrm{M} \mathrm{A} \beta_{1-42}$ or $\mathrm{A} \beta_{3(\mathrm{pE})-42}$ oligomers for $24 \mathrm{~h}$. Cell viability was measured using an MTT assay and is depicted as a percentage of the untreated (minus sign) cells. The graph represents the mean $\pm \operatorname{SEM}(n=16)$ from four independent experiments. ${ }^{*} p<0.01$ as calculated by an unpaired two-tailed Student's $t$ test

data indicate that disruption of lysosomal function contributes to $A \beta_{3(p E)-42}$ oligomer toxicity.

Detection of aggregated $\mathrm{A} \beta \mathrm{pE} 3$ in postmortem human brain tissue

To investigate whether these in vitro observations reflect a process that is relevant in the human brain, 
we analyzed postmortem brain tissue of $\mathrm{AD}$ and control patients using an antibody against oligomers of $\mathrm{A} \beta_{3(\mathrm{pE})-42}$, the $\mathrm{O}-\mathrm{A} \beta \mathrm{pE} 3$. Extensive characterization showed that the $\mathrm{O}-\mathrm{A} \beta \mathrm{pE} 3$ detects a conformationspecific epitope because it detects oligomeric aggregates of $A \beta_{3(\mathrm{pE})-42}$ but not monomeric $\mathrm{A} \beta_{3(\mathrm{pE})-42}$ (see Online resource Fig. S1). The epitope is enriched in

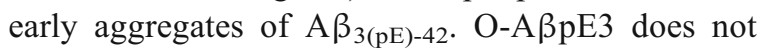
detect $A \beta_{1-42}$ or $A \beta_{3-42}$ oligomers, showing that it is specific for $\mathrm{pE} 3$-modified $\mathrm{A} \beta$ oligomers (Online resource Fig. S1). Remarkably, in postmortem tissue of human brain material, the $\mathrm{O}-\mathrm{A} \beta \mathrm{pE} 3$ antibody does not recognize plaques but showed a strong intracellular staining pattern. This staining pattern is similar on formalin-fixed or frozen tissue sections but is nearly abolished by formic acid pretreatment, indicating that also in brain material the $\mathrm{O}-\mathrm{A} \beta \mathrm{pE} 3$ antibody detects a conformation-specific epitope (Fig. 2a). Aggregates of $\mathrm{A} \beta_{3(\mathrm{pE})-42}$ are structurally different than $\mathrm{A} \beta_{1-42}$ aggregates as indicated by differential recognition by different $A \beta$ antibodies and TEM analysis (Online resource Fig. S2). This is corroborated by the analysis of co-aggregates of $A \beta_{3(p E)-42}$ and $A \beta_{1-42}$, which shows that the antibody only shows strong reactivity with (nearly) pure $\mathrm{A} \beta_{3(\mathrm{pE})-42}$ aggregates (Online resource Fig. S2). These specific properties may explain why the staining pattern is different from that obtained with widely used $\mathrm{A} \beta$ antibodies like $6 \mathrm{E} 10$. Based on the morphology of the cells, intracellular staining could be observed in neurons and glial cells. Neurons showed a diffuse and fine granular staining of the cell body, with no staining of the extensions, whereas the glial cells showed more compact granular staining of the cell body as well as of the extensions. The intraneuronal staining was found predominantly in the pyramidal neurons in layers III and V of the cortex (Fig. 2b), while the intraglial staining was spread throughout all the layers of the cerebral cortex (Fig. 2c). In order to identify which type of glial cells stain positive with the $\mathrm{O}-\mathrm{A} \beta \mathrm{pE} 3$ antibody, double

a

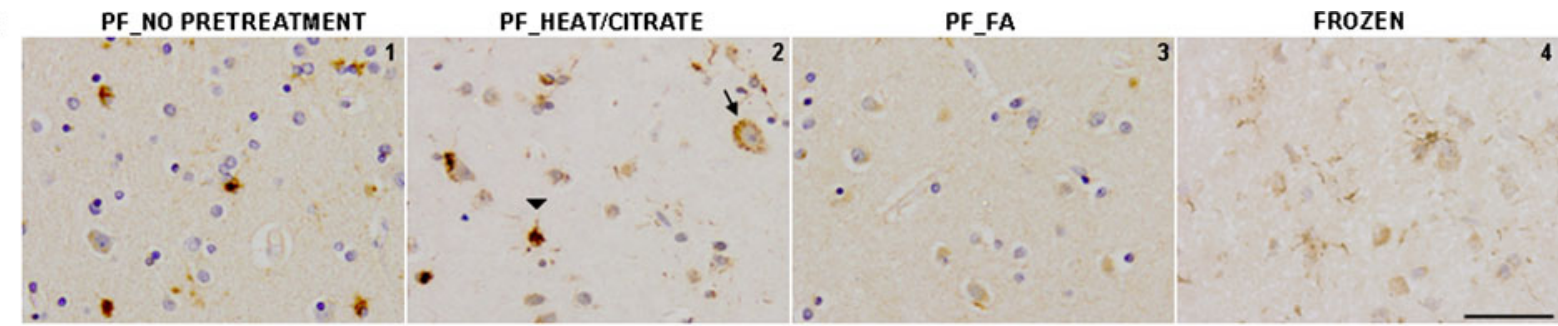

b

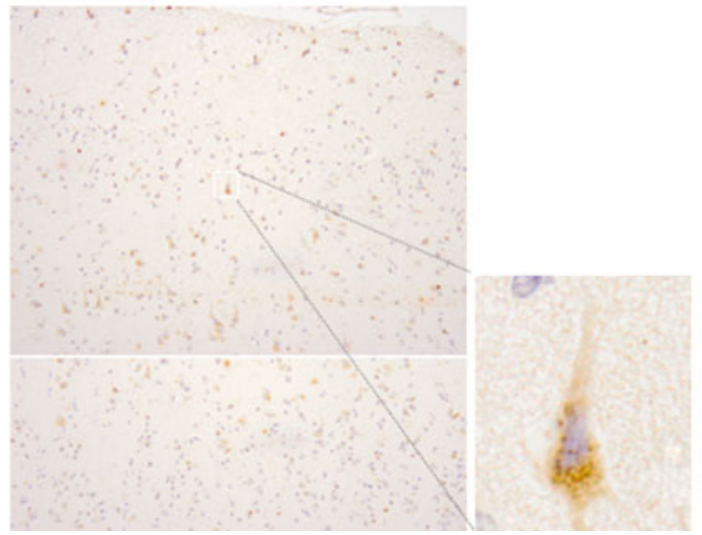

Fig. 2 Detection of aggregated $\mathrm{A} \beta \mathrm{pE} 3$ in postmortem human brain tissue. a Paraffin-embedded (1-3) or frozen (4) sequential sections from temporal cortex of an $\mathrm{AD}$ patient were stained with the $\mathrm{O}-\mathrm{A} \beta \mathrm{pE} 3$ antibody. For the paraffin-embedded sections $(P F)$, different protocols were compared: without antigen retrieval (1) or with antigen retrieval: $10 \mathrm{~min}$ microwave heating in a citric acid buffer $\mathrm{pH} 6$ (2) or 10-min formic acid (FA) pretreatment (3). Arrow depicts a neuron and arrowhead
C

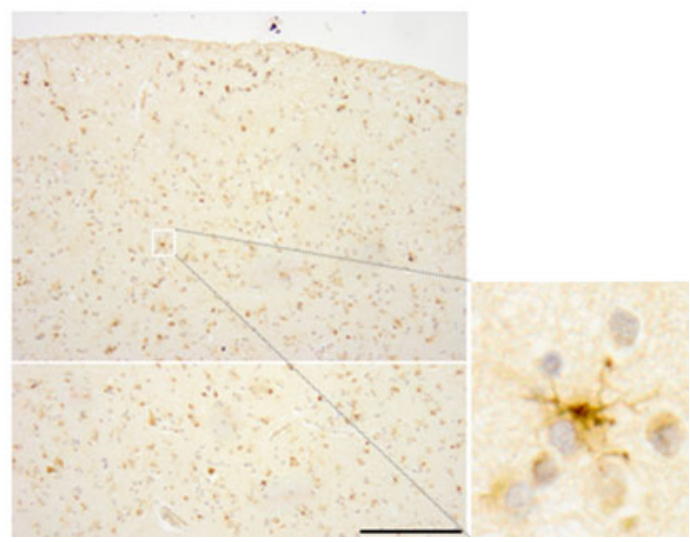

indicates a glial cell. Scale bar (1-4), $50 \mu \mathrm{m}$. b Paraffinembedded heat-treated sections from temporal cortex of an $\mathrm{AD}$ patient stained with the $\mathrm{O}-\mathrm{A} \beta \mathrm{pE} 3$ antibody. Inset shows a higher magnification picture of a neuron. c Paraffin-embedded heat-treated sections from temporal cortex of an $\mathrm{AD}$ patient stained with the O-A $\beta$ pE3 antibody. Inset shows a higher magnification picture of a glial cell. Scale bar, $200 \mu \mathrm{m}$ 
immunohistochemistry (IHC) with microglia- (CR3/43) and astrocyte- (GFAP) specific markers was performed (Fig. 3). The double IHC of GFAP and the O-A $\beta p E 3$ antibody showed two different types of co-localization. Either a strong co-localization of O-A $\beta p E 3$ with GFAP was found (Fig. $3 \mathrm{a}$ ) or O-A $\beta \mathrm{pE} 3$ staining was closely associated with GFAP staining (Fig. 3b). In contrast, no co-localization or association with CR3/43 was observed (Fig. $3 \mathrm{c}$ ). Based on these findings, we conclude that the glial $\mathrm{A} \beta \mathrm{pE} 3$ aggregates are mainly present in astrocytes and not in microglia.

Aggregated $\mathrm{A} \beta \mathrm{pE} 3$ is present in the lysosomes of postmortem human brain

To investigate if the aggregated $\mathrm{A} \beta \mathrm{pE} 3$ species observed in the neurons and glial cells of the postmortem brain tissue are also present in the lysosomal compartment, we performed double immunofluorescence. A clear co-localization of the lysosomal marker LAMP-1 and the O-A $\beta$ pE3 antibody was observed in neurons as well as in glial cells (Fig. 4). Some LAMP1 -negative $\mathrm{O}-\mathrm{A} \beta \mathrm{pE} 3$ staining is observed; however, the majority of the staining co-localizes with LAMP-1. These data demonstrate that the $\mathrm{A} \beta \mathrm{pE} 3$ aggregates accumulate in the lysosomal compartment.

$\mathrm{pE}$ modification confers resistance to lysosomal degradation of $A \beta$

The accumulation of $\mathrm{A} \beta \mathrm{pE} 3$ aggregates in the lysosomal compartment suggests that they are not efficiently degraded. Therefore, we investigated whether the $\mathrm{pE}-$ modified $A \beta$ is more resistant to lysosomal degradation. To this end, a degradation assay with the major lysosomal hydrolase CTD was performed. For this purpose, a
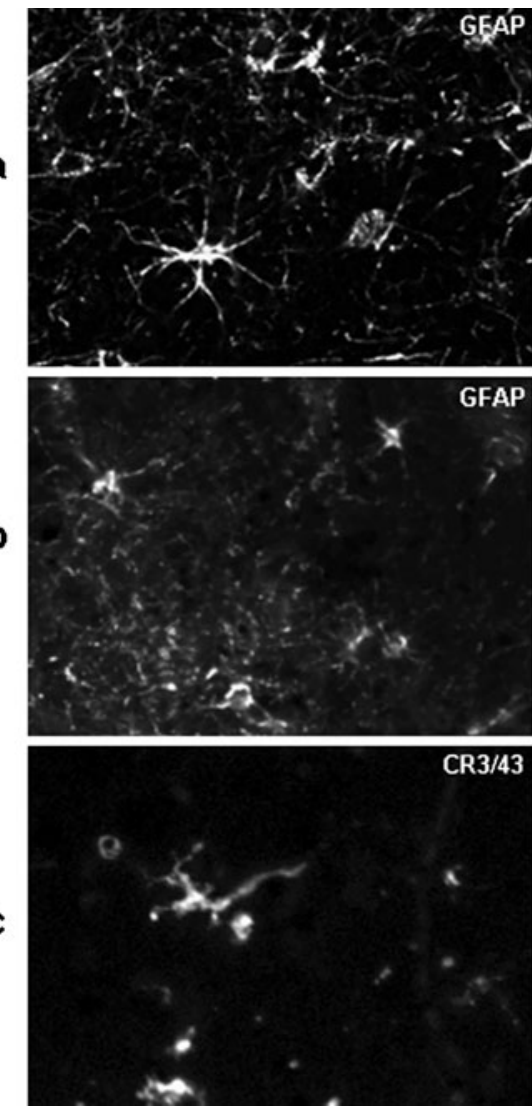
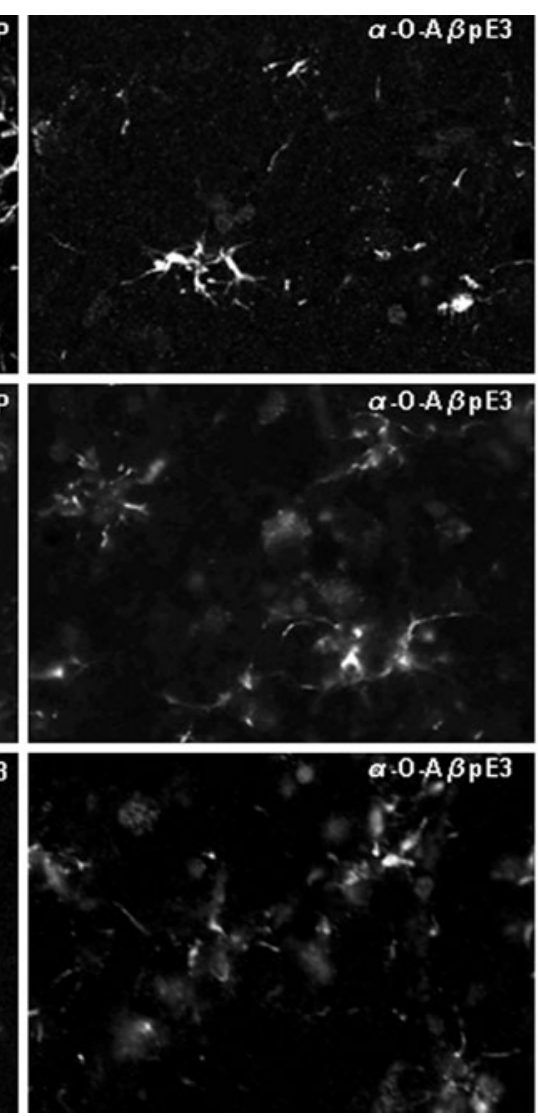
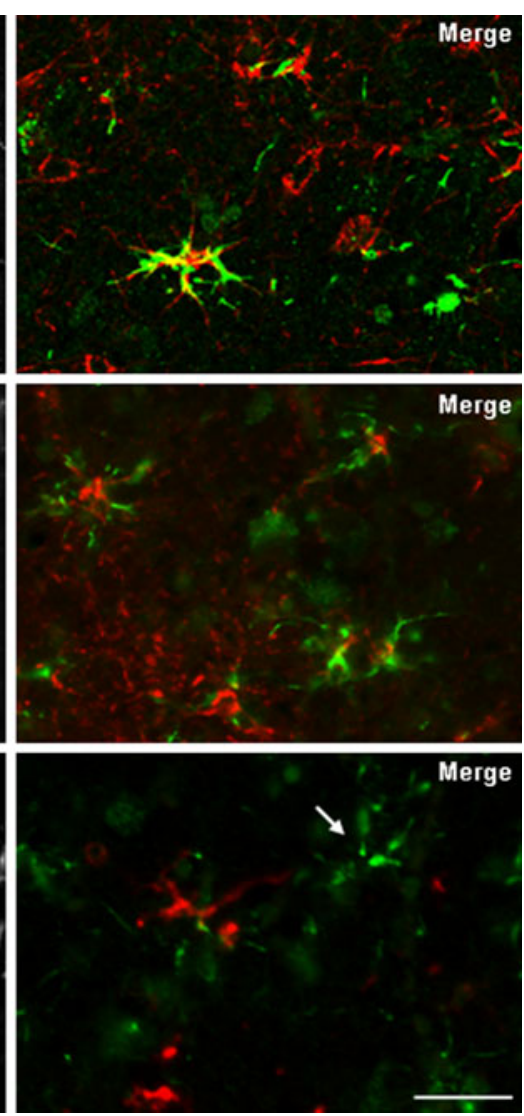

Fig. 3 Intracellular $\mathrm{A} \beta \mathrm{pE} 3$ aggregates are present in astrocytes in human brain. Epifluorescent microscopic images of double fluorescent immunohistochemistry stainings for $A \beta p E 3$ oligomers and GFAP or CR3/43. Paraffin-embedded sections from temporal cortex of an AD patient were double stained with
GFAP (red) as marker for astrocytes $(\mathbf{a}, \mathbf{b})$ or with CR3/43 (red) as a marker for microglia (c), and with the $\mathrm{O}-\mathrm{A} \beta \mathrm{pE} 3$ antibody (green). The arrow shows the typical star-like $\mathrm{O}-\mathrm{A} \beta \mathrm{pE} 3$ staining pattern associated with glial cell staining while CR3/43 staining is clearly absent. Scale bar, $25 \mu \mathrm{m}$ 

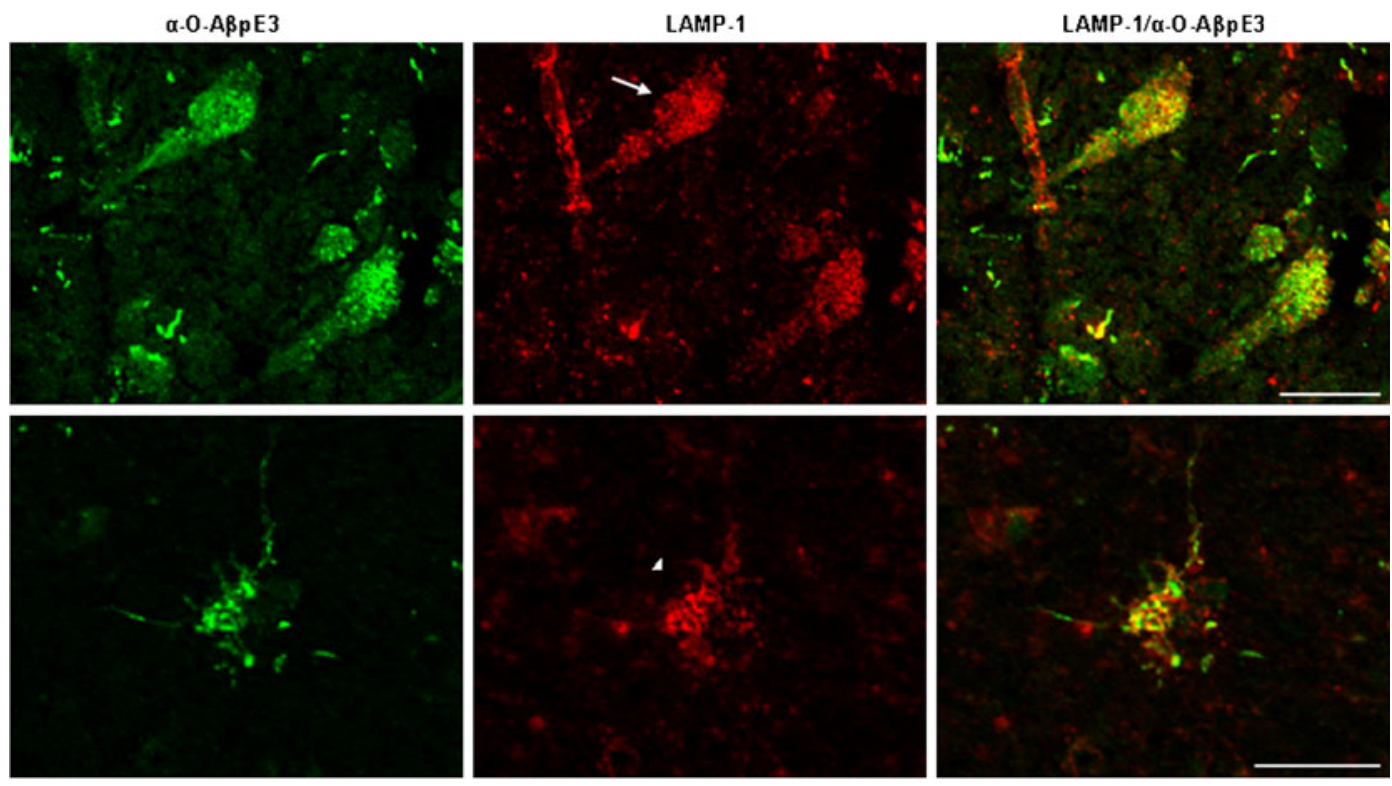

Fig. 4 Aggregated $\mathrm{A} \beta \mathrm{pE} 3$ is present in the lysosomes of postmortem human brain. Confocal microscopic images of frozen sections from temporal cortex of an $\mathrm{AD}$ patient double stained

we used internally quenched fluorescent $A \beta$ peptides. Degradation of the peptides removes the quencher and restores the fluorescent signal (Reits et al. 2003), thus allowing analysis of degradation over time by monitoring the increase in fluorescence. Incubation of $A \beta_{1-40}$ or $\mathrm{A} \beta_{3(\mathrm{pE})-40}$ with $\mathrm{CTD}$ showed a clear increase in with the O-A $\beta \mathrm{pE} 3$ antibody (green) and with a LAMP-1 antibody (red). Co-localization is depicted in yellow. Arrow depicts a neuron and arrowhead indicates a glial cell. Scale bar, $25 \mu \mathrm{m}$

fluorescence indicative of their degradation (Fig. 5). However, the increase in fluorescence observed for the $\mathrm{A} \beta_{3(\mathrm{pE})-40}$ is significantly slower than the increase observed for $A \beta_{1-40}$. Indeed, the time to reach the half-max fluorescence of $\mathrm{A} \beta_{1-40}$ degradation is $48.9 \mathrm{~min}\left(t_{1 / 2}=\right.$ $48.9 \pm 4.3 \mathrm{~min}$, mean $\pm \mathrm{SD}$ ) whereas the half-max

- $A B 1-40=A B 3(D E)-40=A \beta 1-40$ agg $=A B 3(D E)-40$ agg

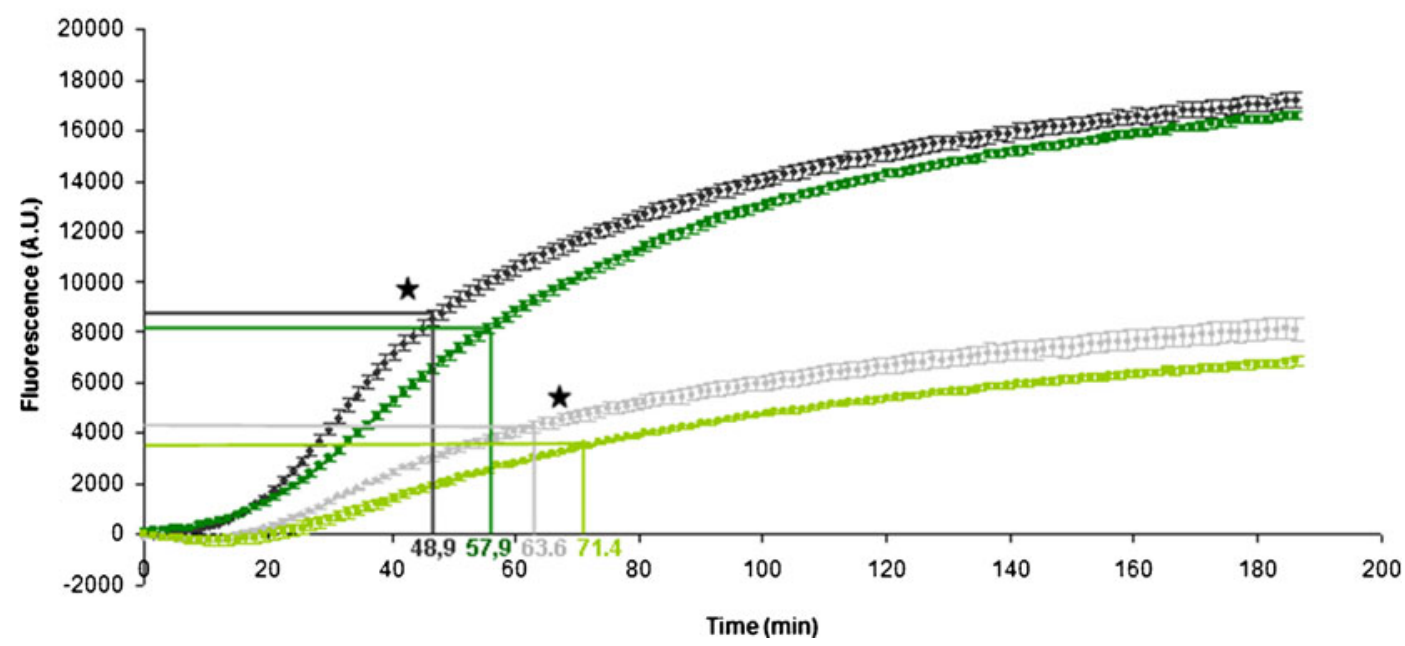

Fig. 5 pE modification confers resistance to lysosomal degradation of $A \beta$. Internally quenched fluorescent $A \beta_{1-40}$ and $\mathrm{A} \beta_{3(\mathrm{pE})-40}$ peptides (pre-aggregated or not) were used in a degradation assay employing recombinant CTD. Degradation of the quenched $A \beta$ peptides is indicated as the accumulated fluorescence over time. The graph represents the mean \pm SEM from two independent experiments $(n=10)$. ${ }^{*} p<0.05$ as calculated by an unpaired two-tailed Student's $t$ test 
fluorescence of $\mathrm{A} \beta_{3(\mathrm{pE})-40}$ degradation is reached at $57.9 \mathrm{~min}\left(t_{1 / 2}=57.9 \pm 3.1 \mathrm{~min}\right.$, mean $\left.\pm \mathrm{SD}\right)$. To investigate the effect of aggregation on degradation, we used pre-aggregated $A \beta_{1-40}$ and $A \beta_{3(p E)-40}$ in the CTD assay. We observed that due to aggregation the reaction is slower and the maximal fluorescence was strongly reduced. This effect is more pronounced for $A \beta_{3(\mathrm{pE})-40}$ than for $A \beta_{1-40}$ since the maximal fluorescence of the $\mathrm{A} \beta_{3(\mathrm{pE})-40}$ degradation is lower than the values reached for $A \beta_{1-40}$ degradation. In addition, the half-max fluorescence of pre-aggregated $A \beta_{1-40}$ degradation is reached at $63.6 \mathrm{~min}\left(t_{1 / 2}=63.6 \pm 10.0 \mathrm{~min}, \operatorname{mean} \pm \mathrm{SD}\right)$ while the half-max fluorescence of pre-aggregated $\mathrm{A} \beta_{3(\mathrm{pE})-40}$ degradation at $71.4 \mathrm{~min}\left(t_{1 / 2}=71.4 \pm\right.$ $2.24 \mathrm{~min}$, mean $\pm \mathrm{SD})$. Upon aggregation, the overall degradation is hampered, but the observed difference between the peptides is retained. These results demonstrate that the pyroglutamate modification in combination with aggregation indeed confers resistance to proteolysis by CTD, which will facilitate their accumulation in the lysosomes.

Intracellular $\mathrm{A} \beta \mathrm{pE} 3$ aggregates increase with age

To obtain further insight in the involvement of aggregates of $\mathrm{A} \beta \mathrm{pE} 3$ during the progression of $\mathrm{AD}$, temporal cortex sections from 16 non-demented controls and $11 \mathrm{AD}$ patients with different Braak scores for $\mathrm{AD}$ pathology were stained with O-AßpE3 (Table 1). The slides were analyzed using a qualitative grading system.

Table 1 Postmortem brain material used in this study

\begin{tabular}{|c|c|c|c|c|c|c|c|c|}
\hline & Diagnosis & Gender & Age & PMD & Break stage & ApoE & Intraneuronal $\mathrm{A} \beta$ & Intraglial $A \beta$ \\
\hline 1 & $\mathrm{AD}$ & $\mathrm{F}$ & 81 & $10: 20$ & VI & 33 & 4 & 4 \\
\hline 2 & $\mathrm{AD}$ & $\mathrm{F}$ & 89 & $04: 30$ & VI & 43 & 4 & 3 \\
\hline 3 & $\mathrm{AD}$ & $\mathrm{M}$ & 69 & 05:00 & VI & 43 & 3 & 4 \\
\hline 4 & $\mathrm{AD}$ & M & 69 & $06: 30$ & VI & 33 & 2 & 2 \\
\hline 5 & $\mathrm{AD}$ & $\mathrm{F}$ & 67 & 05:05 & VI & 32 & 2 & 3 \\
\hline 6 & $\mathrm{AD}$ & $\mathrm{F}$ & 94 & $04: 30$ & $\mathrm{~V}$ & 33 & 4 & 2 \\
\hline 7 & $\mathrm{AD}$ & $\mathrm{M}$ & 93 & $04: 30$ & $\mathrm{~V}$ & 43 & 4 & 4 \\
\hline 8 & $\mathrm{AD}$ & $\mathrm{F}$ & 89 & $06: 30$ & $\mathrm{~V}$ & 33 & 3 & 4 \\
\hline 9 & $\mathrm{AD}$ & $\mathrm{M}$ & 67 & $10: 00$ & $\mathrm{~V}$ & 33 & 2 & 3 \\
\hline 10 & $\mathrm{AD}$ & $\mathrm{F}$ & 95 & $05: 15$ & IV & 33 & 3 & 4 \\
\hline 11 & $\mathrm{AD}$ & $\mathrm{F}$ & 86 & $04: 55$ & IV & 43 & 3 & 3 \\
\hline 12 & $\mathrm{CON}$ & $\mathrm{F}$ & 89 & $15: 40$ & III & 32 & 2 & 3 \\
\hline 13 & $\mathrm{CON}$ & $\mathrm{M}$ & 86 & $05: 35$ & III & 43 & 3 & 4 \\
\hline 14 & $\mathrm{CON}$ & $\mathrm{M}$ & 74 & 05:00 & III & 43 & 4 & 3 \\
\hline 15 & $\mathrm{CON}$ & $\mathrm{F}$ & 93 & 07:05 & II & 33 & 4 & 4 \\
\hline 16 & $\mathrm{CON}$ & $\mathrm{F}$ & 86 & $06: 25$ & II & 43 & 3 & 3 \\
\hline 17 & $\mathrm{CON}$ & $\mathrm{F}$ & 85 & $04: 40$ & II & 43 & 2 & 2 \\
\hline 18 & $\mathrm{CON}$ & $\mathrm{M}$ & 84 & $07: 05$ & I & 33 & 3 & 3 \\
\hline 19 & $\mathrm{CON}$ & $\mathrm{M}$ & 79 & $06: 30$ & I & 33 & 2 & 3 \\
\hline 20 & $\mathrm{CON}$ & $\mathrm{M}$ & 57 & $05: 40$ & I & 43 & 1 & 1 \\
\hline 21 & $\mathrm{CON}$ & $\mathrm{M}$ & 50 & $05: 30$ & I & 33 & 1 & 2 \\
\hline 22 & $\mathrm{CON}$ & $\mathrm{M}$ & 56 & $09: 15$ & 0 & 43 & 3 & 2 \\
\hline 23 & $\mathrm{CON}$ & $\mathrm{F}$ & 41 & $10: 30$ & 0 & 43 & 3 & 2 \\
\hline 24 & $\mathrm{CON}$ & $\mathrm{F}$ & 64 & $08: 35$ & 0 & 42 & 4 & 2 \\
\hline 25 & $\mathrm{CON}$ & $\mathrm{F}$ & 52 & $06: 50$ & 0 & 33 & 4 & 2 \\
\hline 26 & $\mathrm{CON}$ & $\mathrm{F}$ & 61 & $06: 50$ & 0 & 32 & 1 & 3 \\
\hline 27 & $\mathrm{CON}$ & $\mathrm{F}$ & 46 & $10: 25$ & 0 & 33 & 1 & 2 \\
\hline
\end{tabular}

Listed are diagnosis, gender, age (in years), postmortem delay (PMD, in hours: minutes), Braak stage, ApoE genotype, intraneuronal, and intraglial $\mathrm{A} \beta$ staining intensity scored by two independent observers 
The result of this analysis for all the stained slides was summarized in a table (Table 1) and in two scatter plots (Fig. 6). First, we performed nonparametric statistical analysis on the whole cohort confirming that the intraneuronal and the intraglial staining were two independent variables $(r=0.332, p=0.09)$. Subsequently, it was tested whether either staining was correlated to patient data including gender, age, PMD, Braak stage, diagnosis, and ApoE genotype. For the intraneuronal staining, we only found a positive correlation with age $(r=0.442$, $p=0.021)$. For the intraglial staining, a correlation with age $(r=0.628, p<0.001)$, Braak stage $(r=0.524, p=$ $0.005)$, and diagnosis $(r=0.409, p=0.034)$ was found. However, partial correlation analysis showed that after correction for age, intraglial staining was no longer significantly associated with Braak stage $(r=0.267, p=$ $0.187)$ or diagnosis $(r=0.232, p=0.255)$. In contrast, after correction for Braak stage or diagnosis, intraglial staining remained significantly associated with age $(r=$ 0.493, $p=0.01$ and $r=0.564, p=0.003$, respectively). Taken together, this analysis showed that intraneuronal as well as intraglial staining increases with aging. Next, we analyzed the age dependence in relation to the diagnosis. Strikingly, in the control group, the intraneuronal staining did not correlate with age $(r=0.266, p=0.319)$, whereas in the AD group a strong correlation $(r=0.697$, $p=0.017$ ) was still observed. This demonstrated that in the AD group intraneuronal staining increased with age. For the intraglial staining, the correlation remained strictly dependent on age. In the control group, the intraglial staining remained strongly correlated with age $(r=0.745, p=0.001)$; however, within the $\mathrm{AD}$ group the correlation with age $(r=0.259, p=0.443)$ was lost probably because in the $\mathrm{AD}$ group the range of age differences is smaller. In conclusion, these results indicate that intracellular accumulation of aggregated $\mathrm{A} \beta \mathrm{pE} 3$ in glial cells is related to age and in neurons to a combination of age and AD pathology.

\section{Discussion}

In the present study, we investigated the involvement of oligomeric aggregates of $\mathrm{A} \beta \mathrm{pE} 3$ in the pathogenesis of AD. Previously, our group found that oligomeric $A \beta_{1-42}$ is rapidly internalized by neuronal cells to ultimately accumulate in the lysosomal compartment. Inhibition of uptake of oligomeric $A \beta_{1-42}$ decreases toxicity (Chafekar et al. 2008), suggesting that the lysosome is involved in $\mathrm{A} \beta$ toxicity. It was reported before that $A \beta_{1-42}$ could cause LMP (Ditaranto et al. 2001). Using subcellular fractionation and immunofluorescence, we demonstrated that $A \beta_{3(\mathrm{pE})-42}$ oligomers induce LMP more potently than $A \beta_{1-42}$ oligomers. The relevance of

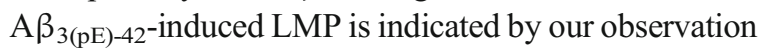
that inhibition of LMP by overexpression of Hsp70 provides protection against $A \beta_{3(\mathrm{pE})-42}$ toxicity. We hypothesize that the observed increase in lysosomal damage after treatment with $\mathrm{A} \beta_{3(\mathrm{pE})-42}$ oligomers compared to oligomers of $A \beta_{1-42}$ is facilitated by their increased

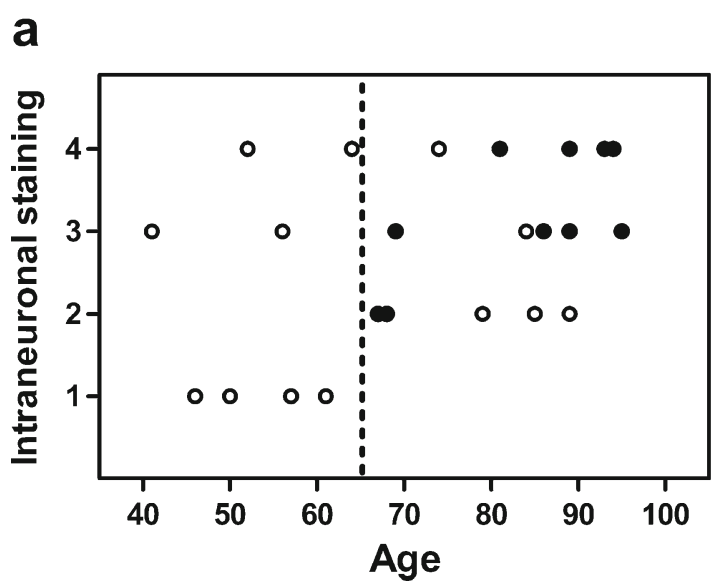

Fig. 6 Intracellular-aggregated $A \beta p E 3$ increases with the progression of $\mathrm{AD}$ pathology and age. Shown are two different scatter plots demonstrating the relation between age and intraneuronal (a) or age and intraglial staining are shown (b). Each b

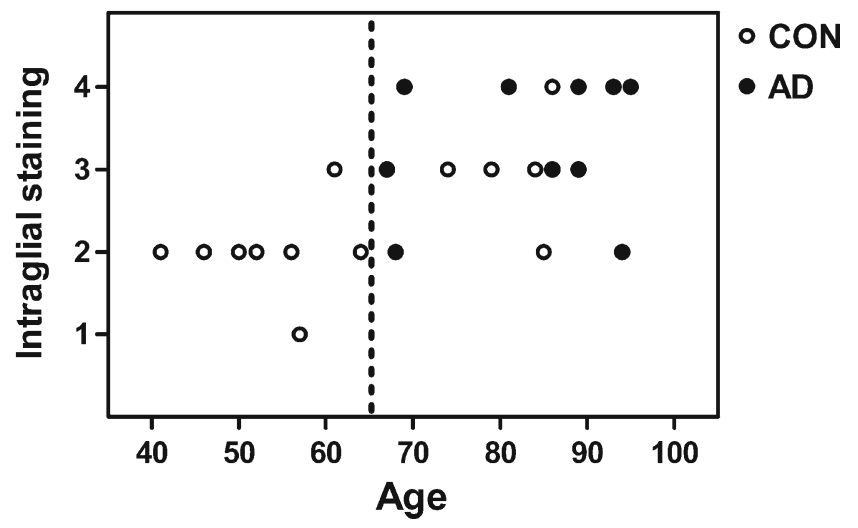

point represents an individual patient where closed circles are diagnosed as $\mathrm{AD}$ and open circles are diagnosed as a control $(C O N)$. The corresponding correlation coefficients are described in the text 
resistance to lysosomal proteolysis, thereby allowing these aggregates to accumulate in the lysosomes. An in vitro lysosomal degradation assay showed that the $\mathrm{pE}$ modification as well as its consequent increased aggregation propensity hampers the degradation of $\mathrm{A} \beta_{3(\mathrm{pE})-40}$ by CTD at lysosomal $\mathrm{pH}$ (Fig. 5).

To further investigate the role of $\mathrm{A} \beta \mathrm{pE} 3$ aggregates in the human brain, a novel antibody was generated against oligomeric $A \beta_{3(\mathrm{pE})-42}$. The antibody is specific for aggregated $3 \mathrm{pE}$-modified $\mathrm{A} \beta$ because it does not detect $A \beta_{3(\mathrm{pE})-42}$ monomers or oligomeric $A \beta_{3-42}$ or $A \beta_{1-42}$. It is likely that the antibody detects $3 p E-$ modified $\mathrm{A} \beta$ of different lengths, as the N-terminus appears as the major determinant of the structure of the aggregates. The addition of two N-terminal residues $\left(\mathrm{A} \beta_{1-42}\right)$ or omission of the N-terminal $\mathrm{pE}$ modification $\left(A \beta_{3-42}\right)$ destroys the conformational epitope (Online resource Fig. S1). This makes it unlikely that aggregates of $\mathrm{N}$-terminal variants like $\mathrm{A} \beta \mathrm{pE} 11$ will be recognized by the antibody. In human postmortem brain tissue, intracellular-aggregated $A \beta p E 3$ was detected in neurons as well as in glial cells. Interestingly, the $\mathrm{O}-\mathrm{A} \beta \mathrm{pE} 3$ does not recognize plaques, whereas it was previously shown that an $A \beta_{1-42}$ oligomer-specific antibody did show plaque binding (Kayed et al. 2003). Recently, a different A $\beta p E 3$ oligomer antibody was reported that also predominantly detects intracellular $\mathrm{A} \beta \mathrm{pE} 3$ in human hippocampus and frontal cortex (Wirths et al. 2010). Analysis of co-aggregates of $A \beta_{3(\mathrm{pE})-42}$ and $A \beta_{1-42}$ (Online resource Fig. S2c) demonstrates that $\mathrm{O}$ $\mathrm{A} \beta \mathrm{pE} 3$ only detects (nearly) pure $\mathrm{pE}$ aggregates. The levels of these specific aggregates may be low compared to the massive $A \beta$ deposits in the plaques and therefore not detected by regular $A \beta$ staining protocols. In addition, it is possible that these aggregates are predominantly present intracellularly, or that the structural epitope is not present or accessible due to different structure of the $\mathrm{A} \beta \mathrm{pE} 3$ in extracellular aggregates. Evidence from transgenic mouse models suggests that the intracellular accumulation of $A \beta$ precedes plaque formation and may play an important role in neurodegeneration (Wirths et al. 2001). Because $A \beta$ peptides are being produced in various cellular compartments of both neurons and glial cells (Hoozemans et al. 2006), it is not surprising that $A \beta$ is found intracellularly. Moreover, in human primary neurons $A \beta$ oligomers have been shown to be produced intracellularly as well, indicating that aggregation can occur inside the cell (Walsh et al. 2000). A second mechanism that may contribute to the intracellular accumulation is reuptake of $A \beta$ peptides from the extracellular space (Chafekar et al. 2008; Nielsen et al. 2010; Nielsen et al. 2009). The uptake of $A \beta$ by astrocytes can be attributed either to their phagocytic capacity (Watabe et al. 1989) or to a receptor-mediated process. Interestingly, receptor for advanced glycation end products (RAGE)-A $\beta$ complexes has been shown to be internalized and colocalize with the lysosomal pathway in astrocytes in AD brain (Sasaki et al. 2001). The minority of the O$\mathrm{A} \beta \mathrm{pE}$ 3-positive structures that is LAMP-1 negative may therefore represent aggregates in the endocytic compartment. It is striking that microglia, the major phagocytosing cells of the brain, do not stain clearly positive for $\mathrm{A} \beta \mathrm{pE} 3$ aggregates. An explanation may be that $\mathrm{pE}$-modified $\mathrm{A} \beta$ is efficiently degraded in microglia and hence does not accumulate in these cells.

Recently, treatment of transgenic mice with retinoid $X$ receptor (RXR) agonists was shown to enhance clearance of $A \beta$ in an ApoE-dependent manner. The data led the authors to conclude that this was mediated by microglial phagocytosis (Cramer et al. 2012). Whether RXR agonists could also be employed to facilitate clearance of $\mathrm{A} \beta \mathrm{pE} 3$ Abeta aggregates by astrocytes and neurons will be interesting to find out. In our neuronal cell culture model, the RXR agonist trans-retinoic acid was present in all conditions, and we cannot exclude that this has affected overall uptake to some extent. The exciting study by Cramer et al. again illustrates the high potential of intervention in the uptake and clearance of $A \beta$ as therapeutic strategy for $\mathrm{AD}$. The semiquantitative analysis of the intracellular $\mathrm{O}-\mathrm{A} \beta \mathrm{pE} 3$ staining in temporal cortex of 16 controls and $11 \mathrm{AD}$ patients showed an agedependent increase in intracellular staining. Moreover for the intraneuronal $\mathrm{O}-\mathrm{A} \beta \mathrm{pE} 3$ staining, this agedependent increase was associated with the disease. This observation underscores the relevance of the oligomeric $A \beta p E$ peptides in the pathogenesis of the disease. The age-related increase in the intraglial $\mathrm{O}$ $\mathrm{A} \beta \mathrm{pE} 3$ staining intensity in control cells might be explained by the resistance of these aggregates against lysosomal degradation. Neuroinflammation is another process that is associated with $\mathrm{AD}$ pathogenesis as well as with aging (Giunta et al. 2008) and it will be interesting to investigate whether the inflammatory 


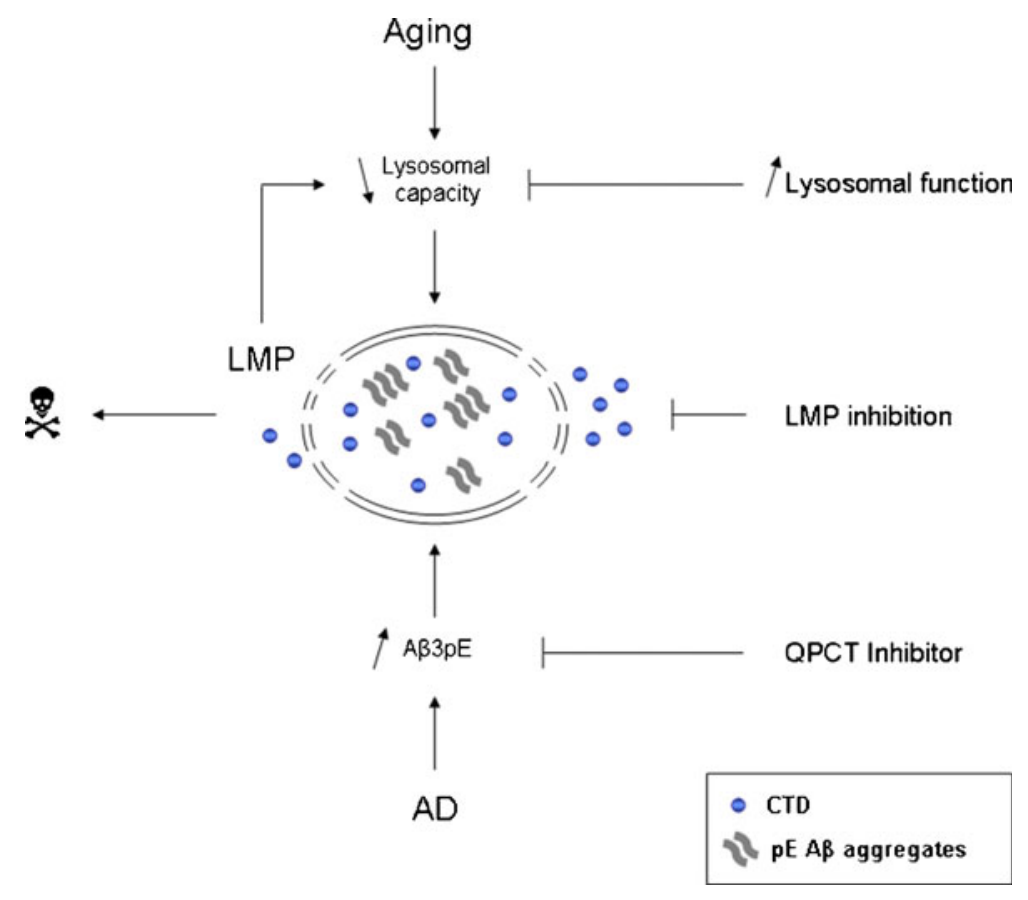

Fig. 7 Model showing convergence of aging and $\mathrm{A} \beta$ toxicity at the lysosome. Due to an age-related decline in lysosomal activity, the degradation of $A \beta$ is hampered resulting in the accumulation of the degradation-resistant $\mathrm{pE}$ variant in the lysosomes. During AD progression, $\mathrm{A} \beta$ and QPCT levels increase which leads to further accumulation. The presence of $p E A \beta$

profile affects the accumulation/clearance of $\mathrm{A} \beta \mathrm{pE}$ peptides. A correlation between intraneuronal $A \beta_{1-x}$ staining and ApoE genotype has been reported (Christensen et al. 2010); however, we did not observe any relation between intracellular oligomeric $\mathrm{pE} A \beta$ and ApoE genotype in our cohort.

Based on our experiments, we propose the following model (Fig. 7). During aging the lysosomal activity declines (Chondrogianni et al. 2002), which hampers the degradation of $\mathrm{A} \beta$ and leads to accumulation of the degradation-resistant $\mathrm{pE}$ variant in the lysosomes. In the progression of $\mathrm{AD}$, this is further compromised by the rise in $\mathrm{A} \beta$ and QPCT levels. The resulting increased load of $\mathrm{pE} A \beta$ aggregates in the lysosomes causes lysosomal damage. Consequently, the lysosomal degradation capacity will decline even further, which may ultimately contribute to neuronal loss. A role for lysosomal dysfunction in AD is supported by data from postmortem brain material: neurons in vulnerable brain regions in $\mathrm{AD}$ patients show an increased number of structurally abnormal aggregates in the lysosomes causes lysosomal damage. Consequently, the lysosomal degradation capacity will decline even further, which may ultimately contribute to neuronal loss. Preventing $A \beta$-induced LMP or enhancing the lysosomal degradation capacity may represent promising therapeutic directions for $\mathrm{AD}$

endosomes, lysosomes, and autophagosomes as well as increased expression of lysosomal hydrolases (Nixon 2007). The convergence of aging and $A \beta$ pathology via decline of the lysosomal pathway is supported by a recently developed conditional Drosophila model linking Alzheimer's neurodegeneration with aging (Ling and Salvaterra 2011). Interestingly, recent evidence indicates that familial AD (FAD) mutations in presenilin 1 (PS1) cause lysosomal impairment (Lee et al. 2010). In this respect, it is striking that the intraneuronal $\mathrm{pE} \mathrm{A} \beta$ staining in PS1 FAD patients is increased compared to sporadic patients (Wirths et al. 2010). This again points to an important role for the lysosome in intracellular $\mathrm{pE} \mathrm{A} \beta$ accumulation. In line with our data and model, a recent report demonstrated that increasing the proteolytic capacity of the lysosome reduces $A \beta$ accumulation in a mouse model (Yang et al. 2011). Our results highlight the potential of $\mathrm{pE} A \beta$ variants as target for intervention in $\mathrm{AD}$. In addition, preventing $\mathrm{pE} A \beta$-induced LMP or enhancing the lysosomal degradation capacity may 
indicate a promising therapeutic direction in agerelated neurodegeneration.

\section{Materials and methods}

Preparation of different amyloid- $\beta$ species $\mathrm{A} \beta_{1-42}$ and $\mathrm{A} \beta_{3-42}$ were purchased from Anaspec (San Jose, CA, USA) and $A \beta_{3(\mathrm{pE})-42}$ was purchased from Bachem (Liestal, Switzerland). All $A \beta$ used in this study is synthetic and therefore free of additional unwanted modifications and endotoxin contamination. Preparations were of the highest available grade of purity ( $>95 \%$ HPLC pure). A $\beta$ oligomers were produced as described before and are ultimately present in aqueous solution buffered at neutral $\mathrm{pH}$ (Chafekar et al. 2007). High-order aggregates were removed by centrifugation (10 $\mathrm{min}, 14,000 \mathrm{rpm})$ at $4{ }^{\circ} \mathrm{C}$. The presence of oligomers was confirmed by electron microscopy and thioflavin T assay.

$\mathrm{A} \beta$ peptides containing fluorophore and quencher were synthesized by solid phase synthesis using an Fmoc strategy at the NKI peptide facility. Oregon green 488 (Molecular Probes, Eugene, OR, USA) was introduced at amino acid 22 by covalent coupling of Oregon green 488 iodoacetamide to the cysteine. Quenching of Oregon green fluorescence was achieved with a dabcyl group that had been introduced in the peptide at amino acid 12 by introduction of Fmoc-L-Lys(Dabcyl)-OH. Peptides were purified by RP-HPLC and evidenced the expected molecular mass as determined by mass spectrometry.

Generation of the $O-A \beta p E 3$ antibody To generate a polyclonal antibody, a chicken was immunized with oligomeric $A \beta_{3(\mathrm{pE})-42}$. First, immunization was performed intradermally with $100 \mu \mathrm{g}$ antigen in Freund's complete adjuvant. Subsequently three boosts were performed with $50 \mu \mathrm{g}$ antigen in Freund's incomplete adjuvant. Eggs were collected and IgY was purified by precipitation with ammonium sulfate and dissolved in TBS with $0.02 \%$ sodium azide.

Cell culture and treatment SK-N-SH and HeLa cells were cultured in Dulbecco's modified Eagle's medium with GlutaMAX (Gibco BRL, Carlsbad, CA, USA) supplemented with $10 \%$ fetal calf serum (FCS, Gibco BRL), $100 \mu \mathrm{g} / \mathrm{ml}$ streptomycin, and $100 \mathrm{U} / \mathrm{ml}$ penicillin. Cell lines are routinely checked for mycoplasma contamination using a specific $16 \mathrm{~S}$ rRNA PCR-based assay; all cells used in this study were mycoplasma free. SK-N-SH cells were differentiated in culture medium supplemented with all trans-retinoic acid (Sigma, St. Louis, MO, USA) at a final concentration of $10 \mu \mathrm{M}$ for 5 days. Differentiated SK-N-SH cells were treated with $30 \mu \mathrm{g} / \mu \mathrm{l}$ hydroxychloroquine (Sigma) for $16 \mathrm{~h}$ or with $1 \mu \mathrm{M} A \beta_{1-42}$ or $\mathrm{A} \beta_{3(\mathrm{pE})-42}$ oligomers for $16 \mathrm{~h}$.

For toxicity experiments, HeLa cells were plated $\left(1 \times 10^{4}\right.$ cells/well in a 96-well plate $)$ and transfected with Hsp70_pcDNA3 (coding sequence of human Hsp70 subcloned into the HindIII and BamHI restriction sites of pcDNA3, kindly provided by Eric Reits, AMC, The Netherlands) using Lipofectamine 2000 (Invitrogen Life Technologies, Carlsbad, CA, USA) according to the manufacturer's protocol. Twentyfour hours after transfection, HeLa cells were treated with $2 \mu \mathrm{M} \mathrm{A} \beta_{3(\mathrm{pE})-42}$ oligomers for another $24 \mathrm{~h}$. Cell viability was estimated by MTT metabolism as previously described (Chafekar et al. 2007). A $\beta$ treatments were performed in culture medium without phenol red.

Dotblot Aliquots of peptide oligomerization reactions were applied onto $0.1 \mu \mathrm{m}$ nitrocellulose membranes (Schleicher and Schuell, Keene, NH, USA), incubated with antibodies (Table 2), and analyzed as previously described (Nijholt et al. 2011).

Subcellular fractionation and Western blotting After treatment, the cells were rinsed with ice cold phosphate-buffered saline (PBS) and subcellular fractionation was performed as described previously (Scheper et al. 2004). Equal amounts of proteins were loaded in $1 \times$ SDS sample buffer on $10 \%$ polyacrylamide gels. Afterwards, the proteins were blotted on PVDF membranes (Millipore, Billerica, MA, USA) and further processed as previously described (Nijholt et al. 2011). The primary antibodies and their dilution factors that were used in this study are listed in Table 2.

Immunocytochemistry Immunohistochemistry on differentiated SK-N-SH cells was performed as described previously (Nijholt et al. 2011). The primary antibodies and their dilution factors that were used in this study are listed in Table 2. Imaging was performed by confocal microscopy using a Leica TCS-SP2 mounted on an inverted microscope. 
Table 2 Primary antibodies and their sources and use

\begin{tabular}{|c|c|c|c|c|}
\hline Antibody & Species & Mono/polyclonal & Dilution & Company \\
\hline \multicolumn{5}{|c|}{ Antibodies for dot blot and Western blot analysis } \\
\hline $6 \mathrm{E} 10$ & Mouse & Monoclonal & $1: 5,000$ & Covance \\
\hline $\mathrm{O}-\mathrm{A} \beta \mathrm{pE} 3$ & Chicken & Polyclonal & $1: 200$ & Hycult Biotech \\
\hline $2-48$ & Mouse & Monoclonal & $1: 5,000$ & Thomas Bayer \\
\hline$A \beta 35-42$ & Mouse & Monoclonal & $1: 2,000$ & Hycult Biotech \\
\hline $\mathrm{A} \beta 38-42$ & Mouse & Monoclonal & $1: 2,000$ & Hycult Biotech \\
\hline Cathepsin D & Goat & Polyclonal & $1: 500$ & $\mathrm{R} \& \mathrm{D}$ systems \\
\hline Calnexin & Rabbit & Polyclonal & $1: 1,000$ & Cell signaling \\
\hline Actin & Mouse & Monoclonal & $1: 1,000$ & Sigma \\
\hline \multicolumn{5}{|c|}{ Antibodies for immunocytochemistry } \\
\hline LAMP-1 & Mouse & Monoclonal & $1: 200$ & Santa Cruz \\
\hline Cathepsin D & Goat & Polyclonal & $1: 100$ & R\&D systems \\
\hline \multicolumn{5}{|c|}{ Antibodies for immunohistochemistry } \\
\hline GFAP & Mouse & Monoclonal & $1: 10$ & Momosan \\
\hline $\mathrm{O}-\mathrm{A} \beta \mathrm{pE} 3$ & Chicken & Polyclonal & $1: 3,200$ & Hycult Biotech \\
\hline $\mathrm{CR} 3 / 43$ & Mouse & Monoclonal & $1: 200$ & Dako \\
\hline LAMP-1 & Mouse & Monoclonal & $1: 100$ & Santa Cruz \\
\hline
\end{tabular}

Listed are antibody, species, mono- or polyclonal, dilution, and company

Degradation assay Immediately prior to use, HFIPtreated peptide films of fluorescently labeled internally quenched $\mathrm{A} \beta$ were resuspended in DMSO and further diluted in PBS. Ten picomoles of $\mathrm{A} \beta$ (pre-aggregated or not) was added to $5 \mathrm{mU}$ of recombinant CTD (Sigma) in $100 \mathrm{mM}$ sodium acetate $\mathrm{pH}$ 5.0. Degradation of quenched peptides was followed by monitoring the increase in fluorescence (excitation, 485-12 nm; emission, $520 \mathrm{~nm}$, Fluostar Omega) at $37{ }^{\circ} \mathrm{C}$. Background fluorescence of peptide incubated in buffer without CTD controls was subtracted. The results were statistically analyzed by Student's $t$ test.

Immunohistochemistry Human brain specimens of probable $\mathrm{AD}$ and non-demented control cases were obtained at autopsy with a short postmortem interval (The Netherlands Brain Bank, Amsterdam, The Netherlands). Informed consent is available for each patient. Clinical diagnosis, gender, age, PMD, Braak stage, and ApoE of all cases used in this study are listed in Table 1. For immunohistochemical staining, formalin-fixed paraffin-embedded tissue and frozen tissue from the mid-temporal cortex was used. Sections (5- $\mu \mathrm{m}$ thick) were mounted on Superfrost plus tissue slides (Menzel-Gläser, Braunschweig, Germany) and dried overnight at $37^{\circ} \mathrm{C}$. For all stainings on the paraffin-embedded tissue, sections were deparaffinized and subsequently immersed in $0.3 \% \mathrm{H}_{2} \mathrm{O}_{2}$ in methanol for $30 \mathrm{~min}$ to quench endogenous peroxidase activity. Either no further treatment was applied, or antigen retrieval was performed by boiling sections for $10 \mathrm{~min}$ in a microwave with $10 \mathrm{mM}$ sodium citrate buffer $\mathrm{pH} 6.0$ or by incubating sections for $15 \mathrm{~min}$ in formic acid. For the stainings on frozen tissue, the sections were treated for $10 \mathrm{~min}$ with acetone. Normal sera and antibodies were dissolved in PBS containing $1 \%(w / v)$ bovine serum albumin (BSA, Boehringer, Mannheim, Germany). Primary antibodies and their sources are listed in Table 2. Negative controls for all single and double immunostainings were generated by omission of primary antibodies.

For detection of $\mathrm{O}-\mathrm{A} \beta \mathrm{pE} 3$, sections were preincubated for $10 \mathrm{~min}$ with normal goat serum (1:10 dilution; DAKO). O-A $\beta p E 3$ (see Table 2) was incubated overnight at $4{ }^{\circ} \mathrm{C}$. After washing with PBS, sections were incubated for $30 \mathrm{~min}$ with biotin-conjugated goat anti-chicken (1:200 dilution, Vector Laboratories, Burlingame, CA, USA). Subsequently, sections were incubated with Vectastain $\mathrm{ABC}$ reagent $(1: 100$, Vector Laboratories) for $60 \mathrm{~min}$. Color was developed using 3,3'-diaminobenzidine (EnVision Detection system/ HRP, 1:50 dilution, $10 \mathrm{~min}$; DAKO) as chromogen. 
Sections were counterstained with hematoxylin and mounted using Depex (BDH Laboratories Supplies, East Grinstead, UK).

Due to the different intracellular O-A $\beta p E 3$ staining patterns in neurons and glial cells, it was decided to score them separately. Scoring was done on the paraffin-embedded tissues heated in sodium citrate buffer before staining by two independent observers blinded to patient data. For each case, the complete gray matter of the section $\left( \pm 1 \mathrm{~cm}^{2}\right)$ was analyzed. The discrimination between neurons and glial cells was based on morphological criteria, e.g., the size of the nucleus and the presence of a clear nucleolus in the nucleus of the neurons. Moreover, as described in the "Results" section, both cell types display a different staining pattern with the O-A $\beta p E 3$ antibody. For the quantification of the intraneuronal staining, the number of positive cells and the staining intensity was taken into account. Level 1 was assigned to cases showing no O-A $\beta$ pE3 staining, level 2 was assigned to cases showing one to five cells with low intensity staining per field using a $\times 40$ objective $\left(0.16 \mathrm{~mm}^{2}\right)$, level 3 was assigned to cases showing one to five cells with high intensity staining as well as to cases showing $>5$ cells with low intensity staining per field, and level 4 was assigned to cases showing $>5$ cells with high intensity staining per field. The intraglial staining did not show great variation in staining intensity so only the number of positive cells was taken into account. Level 1 was assigned to cases showing no OA $\beta$ pE3 staining, level 2 was assigned to cases with $<5$ positive cells per field, level 3 was assigned to cases with 5-10 positive cells per field, and level 4 was assigned to cases showing $>10$ positive cells per field. Nonparametric correlation analysis (bivariate and partial) on the intracellular staining of O-A $\beta$ pE3 antibody was done using the SPSS software.

Double fluorescent immunohistochemistry To determine co-localization of O-A $\beta \mathrm{pE} 3$ with GFAP, CR3/ 43, or with LAMP-1 (see Table 2), sections were preincubated for $10 \mathrm{~min}$ with normal goat serum (1:10 dilution, DAKO). Subsequently sections were incubated overnight at $4{ }^{\circ} \mathrm{C}$ with a mixture of primary antibodies. After washing with PBS, sections were incubated for $60 \mathrm{~min}$ with a mixture of biotinconjugated goat anti-chicken (1:200 dilution, Vector Laboratories) and ALEXA594-conjugated goat anti- mouse (1:400 dilution, Molecular Probes). To visualize the sections stained with LAMP-1, a Cy3-conjugated donkey anti-mouse (1:200 dilution, Jackson Immuno Research, Westgrove, PA, USA) was used. After washing with PBS, sections were incubated for $60 \mathrm{~min}$ with streptavidin-ALEXA488 (1:750 dilution, Molecular Probes). Autofluorescence was quenched using the lipid dye Sudan Black B. Sections were mounted with Aqua Poly/Mount (Polysciences). Imaging was performed by confocal microscopy using a Leica TCS-SP2 mounted on an inverted microscope.

Acknowledgments Human brain tissue was obtained from the Netherlands Brain Bank. We thank Frank Baas for critical reading of the manuscript, Jan van Marle and Ron Hoebe for assistance with the CLSM, Jan Ruijter for assistance with the statistical analysis, Huib Oova and Dris el Atmioui for technical assistance in peptide synthesis, Eric Reits for advice and stimulating discussions about peptide degradation, Pieter Jelle Visser for establishing the EDAR consortium, and Thomas Bayer for providing the 2-48 antibody. This study was supported by the European Commission as part of the sixth Framework Program (EDAR, contract \# 37670) and the seventh Framework program (NAD, grant agreement \# 212043), Internationale Stichting Alzheimer Onderzoek Nederland (ISAO \#07506), and the Netherlands Organisation for Scientific Research (NWO; Meervoud Grant \#836.05.060).

Open Access This article is distributed under the terms of the Creative Commons Attribution License which permits any use, distribution, and reproduction in any medium, provided the original author(s) and the source are credited.

\section{References}

Boya P, Andreau K, Poncet D, Zamzami N, Perfettini JL, Metivier D, Ojcius DM, Jaattela M, Kroemer G (2003) Lysosomal membrane permeabilization induces cell death in a mitochondrion-dependent fashion. J Exp Med 197:1323-1334

Chafekar SM, Hoozemans JJ, Zwart R, Baas F, Scheper W (2007) Abeta 1-42 induces mild endoplasmic reticulum stress in an aggregation state-dependent manner. Antioxid Redox Signal 9:2245-2254

Chafekar SM, Baas F, Scheper W (2008) Oligomer-specific Abeta toxicity in cell models is mediated by selective uptake. Biochim Biophys Acta 1782:523-531

Chondrogianni N, Fragoulis EG, Gonos ES (2002) Protein degradation during aging: the lysosome-, the calpain- and the proteasome-dependent cellular proteolytic systems. Biogerontology 3:121-123

Christensen DZ, Schneider-Axmann T, Lucassen PJ, Bayer TA, Wirths O (2010) Accumulation of intraneuronal Abeta correlates with ApoE4 genotype. Acta Neuropathol 119:555-566 
Cramer PE, Cirrito JR, Wesson DW, Lee CY, Karlo JC, Zinn AE, Casali BT, Restivo JL, Goebel WD, James MJ, Brunden KR, Wilson DA, Landreth GE (2012) ApoE-directed therapeutics rapidly clear $\beta$-amyloid and reverse deficits in $A D$ mouse models. Science. doi:10.1126/science. 1217697

De Kimpe L, Scheper W (2010) From alpha to omega with Abeta: targeting the multiple molecular appearances of the pathogenic peptide in Alzheimer's disease. Curr Med Chem 17:198-212

Ditaranto K, Tekirian TL, Yang AJ (2001) Lysosomal membrane damage in soluble Abeta-mediated cell death in Alzheimer's disease. Neurobiol Dis 8:19-31

Giunta B, Fernandez F, Nikolic WV, Obregon D, Rrapo E, Town T, Tan J (2008) Inflammaging as a prodrome to Alzheimer's disease. J Neuroinflammation 5:51-66

Haass C, Selkoe DJ (2007) Soluble protein oligomers in neurodegeneration: lessons from the Alzheimer's amyloid betapeptide. Nat Rev Mol Cell Biol 8:101-112

Hardy J, Selkoe DJ (2002) The amyloid hypothesis of Alzheimer's disease: progress and problems on the road to therapeutics. Science 297:353-356

Hoozemans JJ, Chafekar SM, Baas F, Eikelenboom P, Scheper W (2006) Always around, never the same: pathways of amyloid beta induced neurodegeneration throughout the pathogenic cascade of Alzheimer's disease. Curr Med Chem 13:2599-2605

Kayed R, Head E, Thompson JL, McIntire TM, Milton SC, Cotman CW, Glabe CG (2003) Common structure of soluble amyloid oligomers implies common mechanism of pathogenesis. Science 300:486-489

Kirkegaard T, Roth AG, Petersen NH, Mahalka AK, Olsen OD, Moilanen I, Zylicz A, Knudsen J, Sandhoff K, Arenz C, Kinnunen PK, Nylandsted J, Jaattela M (2010) Hsp70 stabilizes lysosomes and reverts Niemann-Pick diseaseassociated lysosomal pathology. Nature 463:549-553

Kuo YM, Webster S, Emmerling MR, De LN, Roher AE (1998) Irreversible dimerization/tetramerization and posttranslational modifications inhibit proteolytic degradation of A beta peptides of Alzheimer's disease. Biochim Biophys Acta 1406:291-298

Lee JH, Yu WH, Kumar A, Lee S, Mohan PS, Peterhoff CM, Wolfe DM, Martinez-Vicente M, Massey AC, Sovak G, Uchiyama Y, Westaway D, Cuervo AM, Nixon RA (2010) Lysosomal proteolysis and autophagy require presenilin 1 and are disrupted by Alzheimer-related PS1 mutations. Cell 141:1146-1158

Ling D, Salvaterra PM (2011) Brain aging and Abeta(1-42) neurotoxicity converge via deterioration in autophagylysosomal system: a conditional Drosophila model linking Alzheimer's neurodegeneration with aging. Acta Neuropathol 121:83-91

Nielsen HM, Veerhuis R, Holmqvist B, Janciauskiene S (2009) Binding and uptake of A beta1-42 by primary human astrocytes in vitro. Glia 57:978-988

Nielsen HM, Mulder SD, Belien JA, Musters RJ, Eikelenboom P, Veerhuis R (2010) Astrocytic A beta 1-42 uptake is determined by A beta-aggregation state and the presence of amyloid-associated proteins. Glia 58:1235-1246

Nijholt DA, de Graaf TR, van Haastert ES, Oliveira AO, Berkers CR, Zwart R, Ovaa H, Baas F, Hoozemans JJ, Scheper W (2011) Endoplasmic reticulum stress activates autophagy but not the proteasome in neuronal cells: implications for Alzheimer's disease. Cell Death Differ 18:1071-81

Nixon RA (2007) Autophagy, amyloidogenesis and Alzheimer disease. J Cell Sci 120:4081-4091

Nixon RA, Yang DS, Lee JH (2008) Neurodegenerative lysosomal disorders: a continuum from development to late age. Autophagy 4:590-599

Reits E, Griekspoor A, Neijssen J, Groothuis T, Jalink K, van Veelen P, Janssen H, Calafat J, Drijfhout JW, Neefjes J (2003) Peptide diffusion, protection, and degradation in nuclear and cytoplasmic compartments before antigen presentation by MHC class I. Immunity 18:97-108

Russo C, Violani E, Salis S, Venezia V, Dolcini V, Damonte G, Benatti U, D'Arrigo C, Patrone E, Carlo P, Schettini G (2002) Pyroglutamate-modified amyloid beta-peptidesAbetaN3(pE) - strongly affect cultured neuron and astrocyte survival. J Neurochem 82:1480-1489

Saido TC, Yamao-Harigaya W, Iwatsubo T, Kawashima S (1996) Amino- and carboxyl-terminal heterogeneity of beta-amyloid peptides deposited in human brain. Neurosci Lett 215:173-176

Sasaki N, Toki S, Chowei H, Saito T, Nakano N, Hayashi Y, Takeuchi M, Makita Z (2001) Immunohistochemical distribution of the receptor for advanced glycation end products in neurons and astrocytes in Alzheimer's disease. Brain Res 888:256-262

Scheper W, Zwart R, Baas F (2004) Rab6 membrane association is dependent of Presenilin 1 and cellular phosphorylation events. Brain Res Mol Brain Res 122:17-23

Schilling S, Hoffmann T, Manhart S, Hoffmann M, Demuth HU (2004) Glutaminyl cyclases unfold glutamyl cyclase activity under mild acid conditions. FEBS Lett 563:191-196

Schilling S, Lauber T, Schaupp M, Manhart S, Scheel E, Bohm G, Demuth HU (2006) On the seeding and oligomerization of pGlu-amyloid peptides (in vitro). Biochemistry 45:12393-12399

Schilling S, Zeitschel U, Hoffmann T, Heiser U, Francke M, Kehlen A, Holzer M, Hutter-Paier B, Prokesch M, Windisch M, Jagla W, Schlenzig D, Lindner C, Rudolph T, Reuter G, Cynis H, Montag D, Demuth HU, Rossner S (2008) Glutaminyl cyclase inhibition attenuates pyroglutamate Abeta and Alzheimer's disease-like pathology. Nat Med 14:1106-1111

Walsh DM, Tseng BP, Rydel RE, Podlisny MB, Selkoe DJ (2000) The oligomerization of amyloid beta-protein begins intracellularly in cells derived from human brain. Biochemistry 39:10831-10839

Watabe K, Osborne D, Kim SU (1989) Phagocytic activity of human adult astrocytes and oligodendrocytes in culture. J Neuropathol Exp Neurol 48:499-506

Wirths O, Multhaup G, Czech C, Blanchard V, Moussaoui S, Tremp G, Pradier L, Beyreuther K, Bayer TA (2001) Intraneuronal Abeta accumulation precedes plaque formation in beta-amyloid precursor protein and presenilin-1 doubletransgenic mice. Neurosci Lett 306:116-120

Wirths O, Breyhan H, Cynis H, Schilling S, Demuth HU, Bayer TA (2009) Intraneuronal pyroglutamate-Abeta 3-42 triggers neurodegeneration and lethal neurological deficits in a transgenic mouse model. Acta Neuropathol 118:487-496

Wirths O, Erck C, Martens H, Harmeier A, Geumann C, Jawhar S, Kumar S, Multhaup G, Walter J, Ingelsson M, Degerman- 
Gunnarsson M, Kalimo H, Huitinga I, Lannfelt L, Bayer TA (2010) Identification of low molecular weight pyroglutamate abeta oligomers in Alzheimer disease: a novel tool for therapy and diagnosis. J Biol Chem 285:41517-24

Yang DS, Stavrides P, Mohan PS, Kaushik S, Kumar A, Ohno M, Schmidt SD, Wesson D, Bandyopadhyay U, Jiang Y, Pawlik M, Peterhoff CM, Yang AJ, Wilson DA, St George-Hyslop P, Westaway D, Mathews PM, Levy E, Cuervo AM, Nixon RA
(2011) Reversal of autophagy dysfunction in the TgCRND8 mouse model of Alzheimer's disease ameliorates amyloid pathologies and memory deficits. Brain 134:258-277

Youssef I, Florent-Bechard S, Malaplate-Armand C, Koziel V, Bihain B, Olivier JL, Leininger-Muller B, Kriem B, Oster T, Pillot T (2008) N-truncated amyloid-beta oligomers induce learning impairment and neuronal apoptosis. Neurobiol Aging 29:1319-1333 